\section{Early Copper and Bronze in South Africa.}

TWWO papers dealing with the primitive working of copper in South Africa, which were presented to Section $\mathrm{H}$ at the South Africa meeting of the British Association, are printed in full in vol. 26 of the South African Journal of Science. The late Dr. P.A. Wagner and Mr. Hugh S. Gordon deal with material obtained. from ancient smelters on the farm Blauwbank, No. 435, in the Waterberg district of the Transvaal, from which it was deduced that the ancient metallurgists had deliberately set out to make bronze. Further, as the original ingot found on the site some years ago and the prills of bronze here dealt with contain nickel and arsenic in notable amounts, it has been suggested that investigation might throw light on the date of these workings in view of the fact that ancient bronze from Egypt and Mesopotamia contains nickel, and yet no very ancient site is known which could have produced the ore required to make a nickeliferous bronze.

Further investigations have established the existence at Blauwbank of no fewer than forty smelting sites, two different types of furnaces, and at least four different types of slag, proving that tin, iron, copper, and bronze were smelted there. Chemical analysis of eleven of the supposed bronze prills and brods prove that some of them are of fairly pure copper, others of arsenical copper and copper spice, while only two contain enough tin to bring them within the definition of true bronze, and these are so rich in arsenic that the application of the term is scarcely warranted. Nearly all contain some percentage of nickel. The analysis of a bronze bangle from Zimbabwe also contains nickel. As other bronzes from Zimbabwe and a piece of bronze from Rooiberg, found by Dr. Frobenius, also contain nickel, it is possible that further investigations may show a connexion between Blauwbank and Rhodesia, especially as no ancient tin-workings are known in Southern Rhodesia.

On the other hand, Mr. G. H. Stanley in a paper on "Primitive Metallurgy in South Africa", while admitting that the specimens he has examined point to a deliberate admixture of tin and copper, holds that the copper ingots are of recent native origin. The specimens from Zimbabwe which were examined were in part from the Rhodesia Museum, Bulawayo, in part specimens submitted by Miss Caton-Thompson from her excavations at Zimbabwe and other ruins of Rhodesia. The museum specimens from Zimbabwe itself were typical tin bronzes approximating so closely to the 90:10 ratio that in all probability they were made by melting together previously smelted copper and tin. No nickel was found in any, though there were traces of cobalt. The metal was of excellent quality and obviously produced by skilled smelters from very fine ores. Of the specimens from other sites, a slug from Renders Ruin was almost pure copper, while a bangle from Niekerk Ruins, Inyanga, contained less tin and more arsenic than the rest. A spear-head from Dhlo-Dhlo was of intermediate position, but with neither nickel nor cobalt in detectable quantities.

Miss Caton-Thompson's specimens-small objects, bangles and the like-exhibited a peculiar blue-green patina which suggested enamel. It was, however, easily removable by dilute hydrochloric acid, leaving a very roughly corroded surface. A bangle gave the analysis copper $87 \cdot 43$, tin $12 \cdot 3$, iron $0 \cdot 08$, nickel nil, cobalt faint trace. A spherical pellet $1.4 \mathrm{~cm}$. in diameter showed copper 98.87 , tin 0.8 , bismuth 0.01 , nickel nil, cobalt nil. Other bangles gave an analysis of copper $89.57, \operatorname{tin} 10.5$, and a piece of thin bronze plating gave approximately the same.
Excepting a brass, the only specimen to show a notable content of nickel was a specimen from Chiwona, an irregular flattened lump of metal weighing about $110 \mathrm{gm}$., evidently a smelting product. The analysis was copper 96.3 , arsenic 1.78 , tin trace, iron 0.42 , nickel $1 \cdot 2$, cobalt slight trace.

Mr. Stanley maintains that the presence of nickel is exceptional rather than characteristic. Nickel is quite a common accompaniment of copper in ores of the latter, but unless its presence is commercially important, it is not usually determined or reported. The analyses of ancient copper objects from Sumeria published by Prof. Desch show only four with nickel exceeding $0 \cdot 25$ per cent, the richest being $3 \cdot 3$. Copper and bronze objects of ancient Egyptian and Babylonian origin seldom show the presence of nickel beyond what might be considered an ordinary impurity. In regard to the possibility of South Africa having been the source of ancient bronzes showing traces of nickel, he holds that such ores might have been obtained from a number of other centres, such as the Caucasus or Asia Minor, where a number of ancient workings are known, and others are probably still undiscovered.

\section{University and Educational Intelligence.}

CAMBridge.-The Ministry of Agriculture and Fisheries has offered to make a grant not exceeding $£ 8500$ in aid of the provision of additional laboratory accommodation at the field station of the Department of Animal Pathology in the University.

The Appointments Committee of the Faculty of Economics and Politics has appointed E. A. G. Robinson, of Corpus Christi College, to be University lecturer in the faculty.

The Council of the Senate has recommended the establishment of a temporary professorship of colloidal physics for three years, and that the professorship be held in the first instance by Dr. E. K. Rideal, of Trinity Hall.

It is proposed to confer the honorary degree of doctor of science on Prof. A. Einstein, Prof. M. Planck, and Sir John Rose Bradford.

At a special congregation of the Senate on May 17, the Right Hon. Stanley Baldwin was elected Chancellor of the University in succession to Lord Balfour, who died on Mar. 19.

LeEDs.-The Corbet-Woodall scholarship in gas engineering, value $\mathfrak{f} 60$ a year, and tenable for three and possibly four years, is being offered for competition. Applications must reach the Clerk to the Senate, the University, Leeds, by June 2.

LoNDON.-Presentation Day at the University was on May 14, the ceremony taking place in the Albert Hall. The new Chancellor, Lord Beauchamp, who presided for the first time, referred in his charge to the new graduates to the re-constitution of the University under the Act of 1926. In the course of next year, he said, it might be expected that the foundation stone would be laid of the buildings on the Bloomsbury site, into which the University would enter in its centenary year (1936). Another important development to which the Chancellor specially referred was the provision of a hall of residence for students. The new Principal, Dr. E. Deller, in his Report, also referred to the re-constitution. "There are still some matters outstanding - the revision and (it is hoped) the simplification of our regulations, and the delegation of powers are examples-but satisfactory progress is being made." The total number of candidates for 
all examinations, the Report stated, was 36,633 as against 11,937 in 1913 and 34,941 last year. The candidates for first degrees were 3436 and for higher degrees 510. Of the 3436 candidates for first degrees, 2458 were internal and 1488 external students. There are now 10,200 intermal students. Nothing of outstanding scientific interest is included in the Report, but among recent developments reference is made to the establishment of the University Observatory at Mill Hill Park and to the institution of a chair of social biology at the London School of Economics.

Manchester.- Notice is given of the offer of a Grisedale research scholarship in either botany or

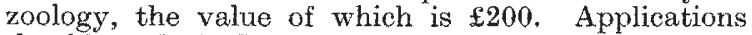
should reach the Registrar of the University by June 2 at the latest.

Str Walter Buchanan-RIDderc, principal of Hert ford College, Oxford, has been appointed by the Lords Commissioners of the Treasury to be chairman of the University Grants Committee in succession to the late Sir William MeCormick.

AN examination of candidates for the associateship of the Institute of Physics will be held in September next. Applications for entry for the examination must be received by the Secretary of the Institute, 1 Lowther Gardens, S.W.7, not later than July 31

A FELtowshrp of the annual value of $£ 300$, and tenable for two years, is being offered by the Company of Armourers and Brasiers, for research in aeronautics. Applications, upon a form obtainable from the Clerk, Armourers' Hall, 81 Coleman Street, E.C.2, must be sent in by, at latest, May 30 .

THE Empire Cotton-growing Corporation is offering a number of $(a)$ specialist studentships, and $(b)$ agricultural studentships, particulars as to the tenure and value of which may be obtained from the Secretary of the Corporation, Millbank House, 2 Wood Street, S.W.1. The Specialist Studentships are intended to enable graduates who believe that they have a leaning towards research to equip themselves for posts in which work of that type is required. The Agricultural Studentships are intended to enable men to receive specialised instruction to equip them for agricultural posts in cotton-growing countries, whether in Government Agricultural Departments, with commereial cotton-growing companies, or under the Corporation. Completed forms of application must reach the Corporation by June 4 .

THE Council of the Institution of Electrical Engineers has established the following scholarships, the first awards of which will be made this year: Duddell Scholarship (annual value $£ 150$, tenable for 3 years). Each candidate must be nominated (not later than June 15) by a corporate member of the Institution. The award is open to British subjects less than nineteen years of age on July 1 , who have passed the matricula. tion examination of a British university or an examina tion exempting from matriculation : Ferranti Scholar ship (annual value $\$ 250$, tenable for 2 years). Each candidate must be nominated (not later than Aug. 15) by the professor or teacher under whom he is working or has worked. The award is open to British subjects less than twenty-six years of age on July 1 who are students or graduates of the Institution of not less than two years'standing. Particulars can be obtained from the Secretary of the Institution, Savoy Place, London, W.C.2.
Historic Natural Events.

May 25, 1269. Prolonged Winter.-The winter of 1268-69 was very rigorous in Great Britain, northern Europe, and Germany. In Alsace it was prolonged until May 25. Holinshed (1578) records that " an exceeding great frost began at St. Andrew's tide (Nov. $30)$ and continued till near Candlemas. The Thames, from the bridge upwards, was so hard frozen that men and beasts passed over. Ships could not enter the Thames, so merchandise was brought to London from Sandwich and other places by land." The Baltic was frozen between Gothland and the Swedish coast.

May 25, I686. Hailstorm at Ryssel (Lille).-Hailstones fell at Lille weighing from one quarter to one pound or more on May 25, 1686. One had dark brown matter in the middle, which when thrown into the fire gave a loud report. The others were transparent and melted immediately. The storm passed over the citadel and town, and not a pane of glass was left on the windward side. Trees were broken and beaten down, and partridges and hares were killed in abundance.

May 26, I9I6. Eruptive Solar Prominence.-A remarkable eruptive prominence, reaching the unprecedented height of $18^{\prime}$ (about 500,000 miles) above the sun's limb, was photographed in India with the spectroheliographs at Kodaikanal and Srinagar. Between $8^{\mathrm{h}} 6^{\mathrm{m}}$ and $9^{\mathrm{h}} 9^{\mathrm{m}}$ (Indian Standard Time) the prominence rose with inereasing velocity from a height of $130^{\prime \prime}$ to $15^{\prime}$. At $9^{\mathrm{h}} 9^{\mathrm{m}}$ the bullk of the prominence had suddenly disappeared, leaving a group of bright points at a height of $13^{\prime}$ to $17^{\prime} ;$ at $9^{\mathrm{h}} 22^{\mathrm{m}}$ or about $1^{\mathrm{h}} \mathrm{h}$ after the first photograph, this small group of points was faintly visible $16^{\prime}$ to $18^{\prime}{ }^{\prime}$ above the sun's limb. The general movement of ascent of the prominence ranged from $80 \mathrm{~km}$. $/ \mathrm{sec}$. to $290 \mathrm{~km}$. $/ \mathrm{sec}$., whilst the greatest velocity of movements of points within it was $450 \mathrm{~km}$. $/ \mathrm{sec}$. It may be remarked that this great eruption occurred outside the sunspot zones.

May 28, 1856. Rhone Floods.-Serious flooding existed in the upper Rhone and especially the Saone on May 11-20, and the waters had scarcely begun to fall before another flood set in on May 24-26. On the evening of May 28 a general heavy fall of rain began and continued for nearly forty-eight hours; at several places totals of more than 4 inches in twenty-four hours were recorded. The floods of the Drac, the lower Isère, the upper Danube, and the Rhone at Lyons, exceeded all records, and persisted for thirtysix hours. The level rose 30 feet above normal at Beaucaire, all the dykes were broken, many bridges were carried away, and the low-lying parts of Lyons on the left bank were partly destroyed. An enormous area was flooded between Tarascon and the sea, and all the crops were ruined.

May 29, I6I3. Cloudburst.-An enormous ' cloudburst occurred in Thuringen, lasting eleven hours, and was followed by unparalleled floods, remembered for a century under the name of the "Thuringian Deluge ". At the same time there were great floods in Saxony, Bohemia, and Austria.

May 29, I9I9. Great Eclipse Prominence.-A great arched prominence, nearly 300,000 miles in length and more than 100,000 miles in height, was a conspicuous naked-eye object within the coronaduring the total solar eclipse of May 28-29-the occasion when the displacement of a ray of light caused by the gravitational field of the sun (as predicted by Einstein) was first measured. This prominence, as shown by spectroheliograms taken at Cambridge, Kodaikanal, and Yerkes, had been in existence since Mar. 22, and at the time of the ec ipse 